\title{
NITROGEN SOIL BUDGETS IN CONTRASTING DAIRY GRAZING SYSTEMS OF SOUTHERN CHILE, A SHORT- TERM STUDY
}

\author{
Núñez, R.P. ${ }^{1}$, Demanet, R. ${ }^{2}$, Alfaro, M. ${ }^{3}$ and Mora, M.L. ${ }^{2 *}$ \\ ${ }^{1}$ Dominican Republic Institute of Agricultural and Forest Research. Calle Rafael Augusto \\ Sánchez No 89, Ensanche Evaristo Morales, Santo Domingo, República Dominicana; ${ }^{2}$ Scientific \\ and Technological Bioresources Nucleus (BIOREN), Universidad de La Frontera, PO Box 54-D, \\ Temuco. Chile; ${ }^{3}$ National Institute for Agricultural Research, Remehue Research Centre, PO Box \\ 24-O, Osorno, Chile. *Author for correspondence: mariluz@,ufro.cl
}

\begin{abstract}
In recent years, the intensification of livestock production in Southern Chile has resulted in a high potential for environmental damage through nitrogen $(\mathrm{N})$ losses, creating the need for the evaluation of $\mathrm{N}$ flows from these systems. The aim of the research was to determine N budgets and N use efficiency in two grazing systems in Southern Chile. For this, inputs and outputs were measured during one year on two grazing systems (heavy grazing, HG; and light grazing, LG). Also, a control treatment with no grazing (C) was considered. The annual $\mathrm{N}$ soil budget was determined by the difference between all $\mathrm{N}$ inputs ( $\Sigma$ inputs) and all $\mathrm{N}$ outputs ( $\Sigma$ outputs). The results of the experiment indicate that $\mathrm{HG}$ treatments received the biggest $\mathrm{N}$ input (427, 359 and 288 $\mathrm{kg} \mathrm{N} \mathrm{ha}{ }^{-1} \mathrm{yr}^{-1}$ for HG, LG and C treatment, respectively), however this treatment also had the biggest $\mathrm{N}$ losses $\left(406 \mathrm{~kg} \mathrm{~N} \mathrm{ha}^{-1} \mathrm{yr}^{-1}\right)$, with a nitrogen recovery efficiency from fertilizer of $71 \%$. In addition, herbage dry matter yield (DM) was greater in the HG than in the LG and $\mathrm{C}$ treatments $\left(10.4 ; 8.1\right.$ and $7.1 \mathrm{t} \mathrm{N} \mathrm{ha}^{-1} \mathrm{yr}^{-1}$, respectively). Also, $\mathrm{N}$ concentration in the forage was higher in this treatment $(2.9 \%)$ than in the LG $(2.7 \%)$ and $\mathrm{C}(2.5 \%)$ treatments. The results indicate that $\mathrm{HG}$ increases $\mathrm{N}$ use efficiency in pastures in Southern Chile, increasing the herbage production and quality, but also increasing the potential for $\mathrm{N}$ losses to the wider environment. Farmers should consider this when choosing the appropriate grazing system.
\end{abstract}

Keywords: Nitrogen budgets, grazing, nitrogen use efficiency, nitrogen losses, pasture.

\section{INTRODUCTION}

The Araucania $\left(37^{\circ}\right.$ to $39^{\circ} \mathrm{S}$ and $\left.70 \mathrm{LW}\right)$ and Los Lagos ( $39^{\circ}$ to $44^{\circ} \mathrm{S}$ and 71 to 74 W) regions in Southern Chile have 7.5 and $9.2 \%$ of the total area for livestock production in Chile, respectively, producing $70 \%$ of the country's milk and $60 \%$ of it's meat (INE, 2007). Livestock production in the area is based on direct grazing on permanent pastures (Alfaro and Salazar, 2005). Over the recent years, these livestock systems have intensified through the use of increasing amounts of nitrogen $(\mathrm{N})$ fertilizer, which can lead to $\mathrm{N}$ losses, potentially affecting the wider environment (Alfaro and Salazar, 2005).

Nitrogen can be lost from the pasture system through ammonia $\left(\mathrm{NH}_{3}\right)$ emissions, through other gaseous $\mathrm{N}$ emissions (dinitrogen, nitric oxide and nitrous oxide; primarily products of 
denitrification) and through nitrate or ammonium leaching (Addiscott, 2006). The fluxes of $\mathrm{N}$ from the pasture depend on environmental and soil conditions (Jarvis and Ledgard, 2002) and $\mathrm{N}$ losses also reduce the productive efficiency of the pasture (Ryden, 1986; Jarvis, 1993; Jarvis, 1997).

Nitrogen budgets have been used in New Zealand as a tool for the evaluation of the environmental impact of $\mathrm{N}$ fertilizer application in grazed areas (Ledgard et al., 1999). In The United Kingdom they have also been used by Jarvis (1993) to compare $\mathrm{N}$ use efficiency between systems. Nitrogen budgets are also used as indicators to assess changes in soil fertility and to quantify soil nutrient status (Lesschen et al., 2007).

In Chile, few $\mathrm{N}$ budget studies have been carried out in grazed systems. However, the importance of the different $\mathrm{N}$ processes in livestock farms has been reported. Alfaro et al. (2005b, 2007, 2009) obtained good results estimating $\mathrm{N}$ budgets to determine the soil fertility conditions, the nutrient use efficiency and the potential environmental impact of the grazing activity.

The quantification of the $\mathrm{N}$ inputs and outputs in grazing systems of Southern Chile is therefore of interest, in order to assess the best grazing management options to increase pasture production with reduced $\mathrm{N}$ losses to the environment. The aim of the research was to quantity $\mathrm{N}$ soil budgets and $\mathrm{N}$ use efficiency (NUE) in two grazing systems in the dairy production area of southern Chile.

\section{MATERIALS AND METHODS}

\section{Experimental site and treatments}

The study was carried out between the $21^{\text {st }}$ September 2005 and the $23^{\text {rd }}$ September 2006, on a permanent pasture
(Lolium perenne L., Festuca arundinacea Schreb., Dactylis glomerata L., and Trifolium repens L.) on an Andisol of Southern Chile $\left(38^{\circ} 50^{\prime} \mathrm{S}, 72^{\circ} 42^{\prime} \mathrm{W}, 70\right.$ m.a.s.l). The soil at the site belongs to the Freire soil Series (Typic Placudands; CIREN, 2003) and had a silty loam texture at the $0-20 \mathrm{~cm}$ soil layer. The soil chemical properties were determined according to the method described by Sadzawka et al. (2000). At the start of the experiment, the soil had a mean Olsen-P concentration of $16 \mathrm{mg} \mathrm{kg} \mathrm{mg}^{-1}$ and an adequate nutritional level for grassland production (Table 1).

Two contrasting grazing treatments together with a no grazing or control (C) were selected from the field assay described in Núñez et al. (2010). Briefly, as follows: Herbage availability (as determined using a rising plate meter at the start of the grazing) was used as criteria for the two grazing treatments (Table 2). Grazing intensities were estimated by the residual pasture postgrazing height, this defined the 'heavy grazing' (HG) or 'light grazing' (LG) treatment as described by Núñez et al. (2010).

The number of grazings per treatments was eight and 10 for the LG and HG treatments, respectively. The average animal intake was 10.3 and $8.1 \mathrm{t} \mathrm{DM} \mathrm{ha}^{-1}$ $\mathrm{yr}^{-1}$ in the $\mathrm{HG}$ and LG treatments, respectively. The grazing times were 26.7 and $20.2 \mathrm{~h}$ for the HG and LG treatments, respectively (Núñez, 2008). In the C treatment, grass was cut seven times during the experimental period when it reached $1400,1400,1150$ or $1150 \mathrm{~kg}$ DM $\mathrm{ha}^{-1}$ depending on the season (Table 2).

Treatments were organized in a randomized block design $(n=3)$, with each paddock being $165 \mathrm{~m}^{2}$ in area. Paddocks were grazed with six Holstein-Friesian non-lactating dairy cows (mean liveweight of $400 \mathrm{~kg}$ ), with an annual average stocking rate of $2.1 \mathrm{LU} \mathrm{ha}^{-1} \mathrm{yr}^{-1}$. 
Table 1. Soil chemical properties by treatments during the period April 2004 to September 2006, Maquehue Station $(0-10 \mathrm{~cm})$. Values given are means for the period, with the standard error of the mean in parentheses $(n=3)^{*}$.

\begin{tabular}{|c|c|c|c|c|}
\hline \multirow[b]{2}{*}{ Property } & \multirow[b]{2}{*}{ Initial value $* *$} & \multicolumn{3}{|c|}{ Treatments*** } \\
\hline & & $\mathrm{C}$ & $\mathrm{HG}$ & LG \\
\hline $\mathrm{pH}\left(\mathrm{H}_{2} \mathrm{O}\right)$ & $5.5(0.07)$ & $5.5(0.06)$ & $5.6(0.09)$ & $5.5(0.07)$ \\
\hline Olsen-P (mg kg $\left.{ }^{-1}\right)$ & $16(0.68)$ & $15.8(0.63)$ & $14.8(1.11)$ & $15.5(0.29)$ \\
\hline $\mathrm{K}\left(\mathrm{mg} \mathrm{kg}^{-1}\right)$ & $250(36.42)$ & 355 (21.24) & $352(65.53)$ & $229(22.49)$ \\
\hline $\mathrm{OM}\left(\mathrm{g} \mathrm{kg}^{-1}\right)$ & $120(0.72)$ & $132(0.75)$ & $117(0.75)$ & $111(0.65)$ \\
\hline Total N $\left(\mathrm{g} \mathrm{kg}^{-1}\right)$ & $5.1(0.18)$ & $5.3(0.13)$ & $5.2(0.16)$ & $5.3(0.31)$ \\
\hline TOC $\left(\mathrm{g} \mathrm{kg}^{-1}\right)$ & $69.6(2.11)$ & $76.6(3.11)$ & $67.7(2.54)$ & $64.7(0.67)$ । \\
\hline $\mathrm{K}\left(\mathrm{cmol}(+) \mathrm{kg}^{-1}\right)$ & $0.6(0.09)$ & $0.9(0.06)$ & $0.9(0.17)$ & $0.6(0.06)$ \\
\hline $\mathrm{Na}\left(\mathrm{cmol}(+) \mathrm{kg}^{-1}\right)$ & $0.3(0.01)$ & $0.1(0.01)$ & $0.1(0.01)$ & $0.1(0.02)$ \\
\hline $\mathrm{Ca}\left(\operatorname{cmol}(+) \mathrm{kg}^{-1}\right)$ & $7.0(0.29)$ & $5.7(0.18)$ & $7.2(0.22)$ & $7.7(0.46)$ \\
\hline $\operatorname{Mg}\left(\operatorname{cmol}(+) \mathrm{kg}^{-1}\right)$ & $1.4(0.11)$ & $1.6(0.14)$ & $1.8(0.12)$ & $1.8(0.08)$ \\
\hline $\mathrm{Al}\left(\operatorname{cmol}(+) \mathrm{kg}^{-1}\right)$ & $0.2(0.06)$ & $0.3(0.06)$ & $0.3(0.07)$ & $0.5(0.06)$ \\
\hline$\Sigma$ Bases $\left(\operatorname{cmol}(+) \mathrm{kg}^{-1}\right)$ & $9.3(0.42)$ & $8.4(0.34)$ & $10.1(0.42)$ & $10.2(0.51)$ \\
\hline $\operatorname{ECEC~}\left(\operatorname{cmol}(+) \mathrm{kg}^{-1}\right)$ & $9.5(0.41)$ & $8.6(0.33)$ & $10.4(0.44)$ & $10.6(0.47)$ \\
\hline $\mathrm{Al}$ saturation $(\%)$ & $2.3(0.64)$ & $2.8(0.59)$ & $3.3(0.66)$ & $4.3(0.67)$ \\
\hline
\end{tabular}

*Average annual soil analysis; ** April 2004; *** September 2006; ECEC, effective cation exchange capacity; OM, organic matter; TOC, total organic carbon; C, no grazing; HG, heavy grazing; LG, light grazing.

Between grazing periods, cows were maintained in a pasture outside of the experimental area.

Urea-N fertilizer was applied to all plots (230 kg N ha $\mathrm{kr}^{-1}$ ) distributed in five dressings $\left(15^{\text {th }}\right.$ October and $15^{\text {th }}$ November of $2005,4^{\text {th }}$ April, $8^{\text {th }}$ May and $17^{\text {th }}$ August (2006), with $46 \mathrm{~kg} \mathrm{~N}$ applied on each occasion. A split dressing (coincidentally with the urea application) of potassium magnesium sulphate ("Sulpomag") was also applied (22\% $\mathrm{K}_{2} \mathrm{O}, 18 \% \mathrm{MgO}, 21.5 \% \mathrm{~S}, 2.5 \% \mathrm{Cl}$ ) at $100 \mathrm{~kg} \mathrm{ha}^{-1}$ on each occasion. Triple super 
Table 2. Dry matter availability $\left(\mathrm{kg} \mathrm{DM} \mathrm{ha}{ }^{-1}\right)$ criteria for the starting and stopping of grazing for each treatment.

\begin{tabular}{lcccc}
\hline \multirow{2}{*}{ Season } & Start/stop of grazing & \multicolumn{3}{c}{ Herbage availability $\left(\mathrm{kg} \mathrm{DM} \mathrm{ha}^{-1}\right)$ per treatment } \\
& & C & HG & LG \\
\hline Spring & Start & No grazing & 2200 & 2600 \\
& Stop & $1400^{\dagger}$ & 1200 & 1600 \\
& Start & No grazing & 2000 & 2400 \\
& Stop & $1400^{\dagger}$ & 1200 & 1600 \\
& Start & No grazing & 1500 & 1800 \\
& Stop & $1150^{\dagger}$ & 1000 & 1300 \\
& Start & No grazing & 1500 & 1300 \\
\hline & Stop & $1150^{\dagger}$ & 1000 & \\
\hline
\end{tabular}

$\overline{{ }^{\dagger} \text { Herbage removed by cutting; DM, dry matter; C, no grazing; HG, heavy grazing; LG, light }}$ grazing.

Phosphate $\left(46 \% \quad \mathrm{P}_{2} \mathrm{O}_{5}\right)$ was applied in autumn $\left(4^{\text {th }}\right.$ April 2006) and winter $\left(17^{\text {th }}\right.$ august 2006) at a rate of $200 \mathrm{~kg} \mathrm{ha}^{-1}$. Lime ("Magnecal 15") and gypsum (fertile gypsum, 18\% S) were applied in March 2006 at a rate of 1000 and $500 \mathrm{~kg}$ $\mathrm{ha}^{-1}$, respectively.

Weather conditions at the experimental site were registered at the Maquehue Station, placed within $1 \mathrm{~km}$ distance of the experimental site (Meteorology Direction of Chile 2005-2006). Total rainfall for the period was $1607 \mathrm{~mm}$, with a daily mean $2.1-5.6 \mathrm{~mm}$ for the grazing season. Daily average was $5.6 \mathrm{~mm} \mathrm{~d}^{-1}$ in winter and $2.1 \mathrm{~mm} \mathrm{~d}^{-1}$ in summer. Average air temperature was greater in summer $\left(14.6^{\circ} \mathrm{C}\right)$, with a range of -4 to $35.5^{\circ} \mathrm{C}$. Average soil temperature was $18.2^{\circ} \mathrm{C}$, ranging from 6 to $21{ }^{\circ} \mathrm{C}$. Soil moisture varied during the year, ranging from 8 to $80 \%$. Wind speed varied between 0.1 and $16.2 \mathrm{~m} \mathrm{~s}^{-1}$.

\section{Nitrogen inputs}

Four sources of $\mathrm{N}$ inputs were considered: atmospheric deposition, applied fertilizer (urea), $\mathrm{N}$ biological fixation (NBF) and recycling ( $\mathrm{N}$ in dung, urine and plant). Deposition of inorganic $\mathrm{N}$ (availability $\mathrm{NO}_{3}^{-}-\mathrm{N}$ and $\mathrm{NH}_{4}{ }^{-}-\mathrm{N}$ ) from rainfall was measured using collectors located in each paddock. The rainwater was regularly collected (approximately each 7-14 days) and analyzed (12-24 h immediately after the sampling) for available nitrate and ammonium concentration by the extraction and distillation analysis (Kjeldahl method; Sadzawka et al., 2000). The cumulative $\mathrm{N}$ deposition was calculated from the $\mathrm{N}$ concentration determined in the sample and the volume 
of rainfall collected for each sampling period.

The chemical fertilization included the inorganic $\mathrm{N}$ added in fertilizer. Nitrogen biological fixation was estimated considering the proportion of white clover (Trifolium repens L.) in the pasture, as described by Ledgard et al. (2001).

Nitrogen recycling from animal excreta was estimated from the grazing time, the paddock area, the $\mathrm{N}$ concentration in dung and urine, and the frequency and volumes of deposition events (urine and dung). Frequency and volumes of urine and dung deposition events were obtained from a separated parallel experiment (Núñez, 2008). The N recycled by the plants was estimated considering a 75\% grazing efficiency (consumed dry matter). The total $\mathrm{N}$ recycling was determined by adding the $\mathrm{N}$ recycled via animal (dung, urine) and plant (kg $\left.\mathrm{N} \mathrm{ha}^{-1} \mathrm{yr}^{-1}\right)$.

\section{Nitrogen outputs}

Outputs considered were $\mathrm{N}$ losses $\left(\mathrm{N}_{2} \mathrm{O}\right.$ emission, $\mathrm{NH}_{3}$ emission, $\mathrm{N}$ leaching) and $\mathrm{N}$ plant uptake.

Nitrogen losses. Nitrous oxide emission from soil was estimated using the factors proposed by the National Greenhouse Gas Inventory Committee (NGGIC, 2005) and the Intergovernmental Panel on Climate Change (IPCC, 1997) for three sources: fertilizer application, recycled $\mathrm{N}$ in dung and recycled $\mathrm{N}$ in urine (fertilizers $(£$ $(\%)=1.25$, dung $(£(\%)=0.5$ and urine $(£$ $(\%)=0.4$ for dry cows, respectively).

Ammonia emissions were determined using static chambers of the same design as those used by Saggar et al. (2004) for measuring nitrous oxide emissions. The chambers were of PVC construction, with a diameter of $250 \mathrm{~mm}$, a height of 210 $\mathrm{mm}$ and a removable lid with an airtight seal. The concentration of ammonium-N in the acid samples was determined spectrophotometrically using the indophenol blue method (Searle, 1984). Cumulative emissions for each season were obtained as the product of the total number of days during the season with the mean of the measured daily emission rates $\left(\mathrm{kg} \mathrm{N} \mathrm{ha}^{-1} \mathrm{yr}^{-1}\right)$.

Nitrogen leaching losses were determined using lysimeter plots. Each lysimeter consisted of a PVC cylinder of $75 \mathrm{~mm}$ diameter and $550 \mathrm{~mm}$ of length. A nylon membrane (pore size of $<0.02 \mathrm{~mm}$ ) separated the soil column in the upper 450 $\mathrm{mm}$ of the cylinder from a leachate collection volume in the lower $100 \mathrm{~mm}$ (Núñez, 2008). A tube travelling from the leachate collection area to the soil surface allowed regular sampling.

The volume of leachate in each lysimeter was measured every $14 \mathrm{~d}$ and sub-samples were taken to determine nitrate and ammonium concentrations. These concentrations were measured by extraction and distillation according to the methodology described by Sadzawka et al. (2000). Nitrogen leaching losses were calculated as the $\mathrm{N}$ concentration determined in the leachates in each lysimeter and the volumen of leachate collected for each sampling period $(\mathrm{kg} \mathrm{N}$ $\mathrm{ha}^{-1} \mathrm{yr}^{-1}$ ).

Plant uptake. Dry matter production was estimated cutting an area of $0.1132 \mathrm{~m}^{2}$ in the pasture before and after grazing and when required in the control treatment. Samples were dried at $65^{\circ} \mathrm{C}$ for $48^{\circ} \mathrm{C}$ or until constant weight. Nitrogen plant uptake was determined in sub samples from those indicated previously and $\mathrm{N}$ concentration was determined by the digestion, distillation and titillation methodology according to Sadzawka et al. (2007). 
Total plant uptake was calculated from $\mathrm{N}$ concentration in the forage and the annual production per treatment.

\section{Nitrogen soil budget}

The $\mathrm{N}$ budget was determined as the difference between $\mathrm{N}$ inputs ( $\Sigma$ inputs) and $\mathrm{N}$ outputs ( $\Sigma$ outputs).

\section{Nitrogen use efficiencies (NUEs)}

Two types of efficiencies were calculated: (1) Nitrogen recovery efficiency (NRE): a) $\mathrm{NRE}(\%) \mathrm{N}$ inputs $=(\mathrm{N}$ uptake by the plants/N inputs total)*100 and b) NRE $(\%)$ of fertilizer $=(\mathrm{N}$ uptake by the plants/ applied nitrogen fertilizer)*100;

Agronomic nitrogen use efficiency (ANUE): a) ANUE $\mathrm{N}$ inputs (kg DM ha ${ }^{-1}$ / $\mathrm{kg} \mathrm{N} \mathrm{ha}^{-1}$ ) = produced $\mathrm{kg} \mathrm{DM} \mathrm{/} \mathrm{kg} \mathrm{N}$ total in the system) and b) ANUE $\mathrm{N}$ inputs fertilizer $\left(\mathrm{kg} \mathrm{DM} \mathrm{ha}{ }^{-1} / \mathrm{kg} \mathrm{N} \mathrm{ha}^{-1}\right)=$ produced $\mathrm{kg} \mathrm{DM} / \mathrm{kg}$ applied $\mathrm{N}$ fertilizer).

\section{Statistical analysis}

ANOVA was used to verify the effect of the treatments in the different parameters described previously used the JMP 5.0.1.2 software (SAS Institute, USA, 2002). Statistical differences of means (95\% significance level) were distinguished using and mean separation Tukey's multiple range test $(P \leq 0.05)$.

\section{RESULTS AND DISCUSSION}

\section{Nitrogen inputs}

The contribution of NBF was greater in the $\mathrm{HG}$ and LG treatments with 34 to $13 \mathrm{~kg} \mathrm{~N}$ $\mathrm{ha}^{-1} \mathrm{yr}^{-1}$, respectively, than the $\mathrm{C}$ treatment with $9.5 \mathrm{~kg} \mathrm{~N} \mathrm{ha}^{-1} \mathrm{yr}^{-1}(P \leq 0.05$; Table 4$)$. This can be related to the greater proportion of legumes in the grazed treatments with 429 (HG) and 192 (LG) $\mathrm{kg} \mathrm{DM} \mathrm{ha}^{-1} \mathrm{yr}^{-1}$ than the control with $144 \mathrm{~kg} \mathrm{DM} \mathrm{ha}^{-1} \mathrm{yr}^{-1}$ (Table 3).

Table 3. Dry mater production, nitrogen concentration, and legume production under different grazing strategies during the period 2005-2006. Values given are means with the standard error in parentheses $(n=3)$.

\begin{tabular}{|c|c|c|c|}
\hline \multirow[b]{2}{*}{ Parameter } & \multicolumn{3}{|c|}{ Treatments } \\
\hline & $\mathrm{C}$ & HG & LG \\
\hline Total dry matter yield (kg DM ha $\left.{ }^{-1} \mathrm{yr}^{-1}\right)$ & $7107 \mathrm{c}(302.5)$ & $10383 a(284.6)$ & $8174 b(171.4)$ \\
\hline Nitrogen concentration (\%) & $2.47 b(0.253)$ & $2.90 \mathrm{a}(0.195)$ & $2.76 \mathrm{a}(0.195)$ \\
\hline Crude protein (\%) & $15.42 \mathrm{~b}(1.194)$ & $18.15 \mathrm{a}(0.988)$ & $17.21 \mathrm{a}(0.996)$ \\
\hline Crude protein yield $\left(\mathrm{kg} \mathrm{CP} \mathrm{ha}{ }^{-1} \mathrm{yr}^{-1}\right)$ & $1095.8 \mathrm{c}(51.25)$ & $1885.6 \mathrm{a}(82.01)$ & $1406.8 b(81.17)$ \\
\hline Clover* annual average (\%) & $2.03 b(0.684)$ & $4.13 \mathrm{a}(1.826)$ & $2.35 b(0.985)$ \\
\hline Clover** (\%) & $0.7-4.2$ & $0.3-13$ & $0.1-5.5$ \\
\hline Total clover production ( $\left.\mathrm{kg} \mathrm{DM} \mathrm{ha} \mathrm{hr}^{-1} \mathrm{yr}^{-1}\right)$ & $144.3 \mathrm{c}(20.50)$ & $428.8 \mathrm{a}(49.26)$ & $192.1 b(30.35)$ \\
\hline
\end{tabular}

Different letters within rows indicate significant differences $(P \leq 0.05)$. DM, dry mater production; CP, crude protein; C, no grazing; HG, heavy grazing; LG, light grazing. * Trifolium repens L.; ** Values minima and maxima. 
The total $\mathrm{N}$ contribution to the system was 288.1, 427.4 and $358.7 \mathrm{~kg} \mathrm{~N} \mathrm{ha}^{-1} \mathrm{yr}^{-1}$ for the $\mathrm{C}$, $\mathrm{HG}$ and $\mathrm{LH}$ treatments, respectively $(P \leq 0.05$; Table 4). Nitrogen input in fertilizer application represented $54-64 \%$ of the total $\mathrm{N}$ input, reaching up to $80 \%$ of the total inputs in the $\mathrm{C}$ treatment). The contribution plant recycling and animals recycling represented between 30 and $37 \%$ of the $N$ inputs in the HG and LG grazing, respectively (Table 4 ). The $\mathrm{N}$ recycled by the incorporation of plant and animal residues (plant + dung + feces) was superior in the $\mathrm{HG}$ compared to $\mathrm{LG}$ and $\mathrm{C}$ treatments, respectively $(P \leq 0.05)$. The lowest $\mathrm{N}$ input was due to rainfall (1.3-1.6 $\%$ of the total), with a total contribution of 4-5 $\mathrm{kg} \mathrm{N} \mathrm{ha}^{-1} \mathrm{yr}^{-1}$ (Table 4).

\section{Nitrogen losses}

Nitrogen leaching losses and gas emissions varied between 67-102 kg N $\mathrm{ha}^{-1} \mathrm{yr}^{-1}$ and were greater in the $\mathrm{HG}$ treatment ( $P \leq 0.05$; Table 4$)$. These losses represented $26 \%$, on average, of the $\mathrm{N}$ outputs in the livestock systems. The accumulated $\mathrm{N}$ losses during the year were significantly greater in the $\mathrm{HG}$ treatment $(P \leq 0.05)$, with $58.7 \mathrm{~kg} \mathrm{~N}^{-1}$ $\mathrm{yr}^{-1}$ compared to $\mathrm{LG}$ and the $\mathrm{C}$ treatments, which did not differ among them. The annual losses of $\mathrm{NH}_{3}$ were 31.2, 39.9 and $37.9 \mathrm{~kg} \mathrm{ha}^{-1} \mathrm{yr}^{-1}$ in $\mathrm{C}, \mathrm{HG}, \mathrm{LG}$, respectively, with no differences between grazing treatments $(P \leq 0.05)$. Nitrous oxide emissions represented between 1.3 to $1.4 \%$ of the $\mathrm{N}$ applied as fertilizer. The annual $\mathrm{N}$ leached represented between 13 and $14.5 \%$ of the $\mathrm{N}$ outputs of the system (Table 4), with the biggest loss in HG $(14.5 \%)$.

\section{Plant uptake}

The dry matter production during the year varied between 7 and $10 \mathrm{t} \mathrm{DM} \mathrm{ha}{ }^{-1}$, according to treatment. The average foliar
$\mathrm{N}$ was among 2.47 to $2.90 \%$, depending of the grazing system and the control treatment (Table 3).

\section{Nitrogen budgets}

The $\mathrm{N}$ budgets were positive in all three treatments (Table 4) varying between 22 and $63 \mathrm{~kg} \mathrm{~N} \mathrm{ha}^{-1} \mathrm{yr}^{-1}$, being smaller in $\mathrm{HG}$ and bigger in $\mathrm{LG}$ and $\mathrm{C}$ treatment. However, the HG treatment showed the lowest surplus with $22 \mathrm{~kg} \mathrm{~N} \mathrm{ha}{ }^{-1} \mathrm{yr}^{-1}$, being followed by the $\mathrm{LG}$ treatment $(63.2$ $\left.\mathrm{kg} \mathrm{N} \mathrm{ha}{ }^{-1} \mathrm{yr}^{-1}\right)$. The surplus in the LG treatment differed from that of the control $(P \leq 0.05)$.

\section{Nitrogen use efficiencies (NUEs)}

Nitrogen recovery efficiency (NRE) and agronomic $\mathrm{N}$ use efficiency (ANUE) were greater in the HG than in the LG and the $\mathrm{C}$ treatment $(P \leq 0.05$; Table 4$)$. This was related to a greater DM production and plant uptake in this treatment (Table 3).

\section{DISCUSSION}

\section{Nitrogen inputs}

Nitrogen deposition in grazing areas of Southern Chile has been reported as low as $3.3 \mathrm{~kg} \mathrm{~N} \mathrm{ha}^{-1} \mathrm{yr}^{-1}$ (Godoy et al., 2001) and much lower values (Godoy et al., 2003). In addition, Boeckx et al. (2004) indicate that in pristine forests from southern Chile, $\mathrm{N}$ deposition varies between $0.2-3.5 \mathrm{~kg} \mathrm{ha}^{-1} \mathrm{yr}^{-1}$. Alfaro et al. (2005a) and Oyarzún et al. (2002) reported values of 3 and $5 \mathrm{~kg} \mathrm{~N} \mathrm{ha}^{-1} \mathrm{yr}^{-1}$, respectively, similar to the values determined in this experiment. The differences shown in the values of nitrogen deposition (4.6 to 4.9) per treatments can be attributed to analytic error (instrumental), since rainfall distribution was uniform between treatments and $\mathrm{N}$ concentration was similar. 
Table 4. Nitrogen soil budgets $\left(\mathrm{kg} \mathrm{N} \mathrm{ha}^{-1} \mathrm{yr}^{-1}\right)$ and nitrogen use efficiencies (NUEs) for the different treatments during the period 2005-2006. Values given are means with the standard error in parentheses $(n=3)$.

\begin{tabular}{|c|c|c|c|}
\hline \multirow[t]{2}{*}{ Inputs and outputs } & \multicolumn{3}{|c|}{ Treatments } \\
\hline & $\mathrm{C}$ & HG & LG \\
\hline \multicolumn{4}{|l|}{ Nitrogen inputs } \\
\hline Atmospheric deposition* & 4.6a ( 0.73) & $4.9 \mathrm{a}(0.67)$ & $4.7 \mathrm{a}(0.73)$ \\
\hline Fertilizer & $230 \mathrm{a}(0.00)$ & $230 \mathrm{a}(0.00)$ & $230 \mathrm{a}(0.00)$ \\
\hline NBF & $9.5 \mathrm{c}(1.07)$ & $33.9 \mathrm{a}(0.78)$ & $13.5 \mathrm{~b}(0.43)$ \\
\hline$($ dung + urine + plant $)$ & $44.0 \mathrm{c}(0.90)$ & $158.6 \mathrm{a}(4.03)$ & $110.5 b(1.04)$ \\
\hline Total $\mathrm{N}$ inputs & $288.1 \mathrm{c}(3.46)$ & $427.4 \mathrm{a}(3.46)$ & $358.7 \mathrm{~b}(4.17)$ \\
\hline \multicolumn{4}{|l|}{ Nitrogen outputs } \\
\hline Denitrification** & $2.9 \mathrm{a}(0.000)$ & $3.2 \mathrm{a}(0.004)$ & $3.1 \mathrm{a}(0.001)$ \\
\hline Volatilization*** & $31.2 b(0.71)$ & $39.9 \mathrm{a}(0.38)$ & $37.9 \mathrm{a}(0.42)$ \\
\hline Leaching* & $33.2 b(0.95)$ & $58.7 \mathrm{a}(2.45)$ & $32.1 \mathrm{~b}(1.59)$ \\
\hline Total N losses & $67.3 b(0.99)$ & $101.8 \mathrm{a}(2.55)$ & $73.1 \mathrm{~b}(1.98)$ \\
\hline Plant uptake & $175.7 \mathrm{c}(5.8)$ & $303.7 \mathrm{a}(12.25)$ & $222.4 \mathrm{~b}(3.88)$ \\
\hline Total $\mathrm{N}$ outputs & $243.0 \mathrm{c}(6.16)$ & $405.5 \mathrm{a}(9.85)$ & $295.5 b(2.13)$ \\
\hline Nitrogen surplus & $45.1 \mathrm{~b}(1.87)$ & $21.9 \mathrm{c}(7.10)$ & $63.2 \mathrm{a}(5.83)$ \\
\hline \multicolumn{4}{|l|}{ Efficiency type } \\
\hline NREF (\%) & $76.4 \mathrm{c}(10.06)$ & $132.0 \mathrm{a}(8.54)$ & $96.7 \mathrm{~b}(12.97)$ \\
\hline NRE inputs (\%) & $61.0 \mathrm{~b}(5.46)$ & $71.1 \mathrm{a}(5.33)$ & $62.0 \mathrm{~b}(7.35)$ \\
\hline ANUE fertilizer $\left(\mathrm{kg} \mathrm{DM} \mathrm{ha}^{-1} / \mathrm{kg} \mathrm{N} \mathrm{ha}^{-1}\right)$ & $30.9 b(4.14)$ & $45.1 \mathrm{a}(5.47)$ & $35.5 \mathrm{~b}(6.41)$ \\
\hline ANUE inputs total $\left(\mathrm{kg} \mathrm{DM} \mathrm{ha}^{-1} / \mathrm{kg} \mathrm{N} \mathrm{ha}^{-1}\right)$ & $24.7 \mathrm{a}(3.35)$ & $24.3 \mathrm{a}(1.93)$ & $22.8 \mathrm{a}(3.62)$ \\
\hline
\end{tabular}

Different letters among rows indicate significant differences $(P \leq 0.05)$. C, no grazing; HG, heavy grazing; LG, light grazing; ${ }^{*} \mathrm{NO}_{3}{ }^{-}-\mathrm{N}+\mathrm{NH}_{4}{ }^{+}-\mathrm{N} ; * * \mathrm{~N}_{2} \mathrm{O}-\mathrm{N} ; * * * \mathrm{NH}_{3}-\mathrm{N}$; NRE, nitrogen recovery efficiency; NREF, nitrogen recovery efficiency fertilizer; ANUE, agronomic nitrogen use efficiency. Different letters among the rows indicate significant differences $(P \leq 0.05)$. 
The fertilization of the pasture used in the present experiment for dairy production was high compared to the fertilization applied in beef production systems of Southern Chile, this is $150-200 \mathrm{~kg} \mathrm{~N}^{-1}$ $\mathrm{yr}^{-1}$ (Alfaro et al., 2006; Alfaro et al., 2007).

The contribution of NBF was greater in the HG and HL, respectively (Table 4). This can be related to the greater proportion of legumes in the grazed treatments (Table 3 ), because this practice favors light penetration to the pasture, which in turn, favor light incidence on the clover growing points (Ledgard et al., 2001).

The contribution of NBF in $\mathrm{HG}$ was about $8 \%$ compared to a $3.8 \%$ and $3.3 \%$ in the $\mathrm{LG}$ and $\mathrm{C}$ treatments, respectively. The results obtained in $\mathrm{HG}$ are comparable to the ones obtained by Urzúa (2005) in permanent pastures of Southern Chile $\left(30 \mathrm{~kg} \mathrm{~N} \mathrm{ha} \mathrm{yr}^{-1}\right)$. In natural pastures, fixation is usually lower $(15 \mathrm{~kg}$ $\left.\mathrm{N} \mathrm{ha}^{-1} \mathrm{yr}^{-1}\right)$, because of lower proportions of clover in the pasture, in agreement with the results obtained in the LG treatment.

Greater amounts of $\mathrm{N}$ recycled to the pasture, as feces and urine, were found in the HG treatment $(P \leq 0.05)$, with values of $83 \mathrm{~kg} \mathrm{~N} \mathrm{ha}^{-1} \mathrm{yr}^{-1}$, compared to the $55 \mathrm{~kg} \mathrm{~N}$ $\mathrm{ha}^{-1} \mathrm{yr}^{-1}$ recycled in the LG treatment. This could be attributed to a greater number of grazing registered during the season in this treatment, which resulted in a greater grazing period, a greater DM animal intake, a greater number of dung and urine patches and thus, a greater $\mathrm{N}$ return to the soil, in agreement with Reyes et al. (2000). These $\mathrm{N}$ inputs to the pasture are vital for an optimal production and also as a compensation process of $\mathrm{N}$ losses by plant uptake, animal uptake, gaseous $\mathrm{N}$ and $\mathrm{N}$ leaching.

The $\mathrm{N}$ recycled by the incorporation of plant and animal residues (plant + dung + feces) was superior in the $\mathrm{HG}$ compared to the $\mathrm{LG}$ and $\mathrm{C}$ treatments $(P \leq 0.05)$. This is attributed to the dry matter yield of this treatment, and the volume of residue generated. Recycling values measured in the present experiment are lower than those reported by Haynes and Williams (1993), Whitehead (2000) and Ledgard et al. (1998, 1999). This could be attributed to the higher stocking rate used in the New Zealand experiments and the animal handling used in our case, where animals were mostly managed outside the experimental paddocks, so that the rumination of the ingested grass was deposited in other areas.

\section{Nitrogen losses}

The annual losses of $\mathrm{NH}_{3}$ were greater in the grazing systems $\left(37.9-39.9 \mathrm{~kg} \mathrm{~N} \mathrm{ha}^{-1}\right)$ than in the control $\left(31.2 \mathrm{~kg} \mathrm{~N} \mathrm{ha}^{-1}\right)$ (Table 4). Jarvis (1993) indicates that the $\mathrm{NH}_{3}$ emission in England was $46 \mathrm{~kg} \mathrm{~N} \mathrm{ha}{ }^{-1}$. Similarly, Ledgard et al. (1998), in New Zealand, reported losses of $41 \mathrm{~kg} \mathrm{~N}^{-1}$ $\mathrm{yr}^{-1}$ with a dose of $200 \mathrm{~kg} \mathrm{~N}$ ha in pasture under irrigations. However, Jarvis and Ledgard (2002) in comparative study in dairy farms from UK and New Zealand system reported great differences in $\mathrm{NH}_{3}$ losses attributed mainly to the cows winter housing. While in UK the $\mathrm{NH}_{3}$ emission reached $57.2 \mathrm{~kg} \mathrm{ha}^{-1}$ in New Zealand the $\mathrm{NH}_{3}$ losses was $24 \mathrm{~kg} \mathrm{ha}{ }^{-1}$. Comparing the results obtained in this experiment with the results reported by Ledgard et al. (1998, 1999) and Jarvis and Legard (2002), a similarity was observed in the emissions $\mathrm{NH}_{3}$ produced in dairy pastures with New Zealand studies. The results suggest that a change in the grazing intensity, independently of the stocking rate, has an effect in the levels of $\mathrm{NH}_{3}$ emissions and therefore in a reduction in the quantity of available $\mathrm{N}$ for plant uptake. This has an effect in turn on the quantity and quality of the pasture.

Volatilized ammonia represented between 10 and $13 \%$ of the $\mathrm{N}$ total 
outputs in the pasture during the year. In addition, $\mathrm{NH}_{3}$ losses represented between 13 and $17 \%$ of the $\mathrm{N}$ applied as urea, in agreement with the $20 \%$ indicated by Sommer and Jensen (1994) for fertilizer applied in grassland soils. Ammonia emissions in grazing systems in template areas represented between 8 and $9 \%$ of the total $\mathrm{N}$ inputs to the system (Bouwman et al., 2005), which also matches with this experiment.

The accumulated $\mathrm{N}$ losses during the year were significantly different (Table 4). Results of the present experiment suggest that grazing has a direct effect on $\mathrm{N}$ leaching losses from the pasture, in agreement with Ryden et al. (1984). The annual losses of leached $\mathrm{N}$ obtained in this experiment are low compared to what reported Di and Cameron (2004) and Ledgard et al. (1999) in irrigated pastures managed under grazing in New Zealand and Australia, respectively, because of differences in stocking rates and $\mathrm{N}$ application as fertilizer (both greater in the New Zealand studies).

The losses produced by leaching could be influenced by edaphic factors, local site history, in agreement with Ledgard et al. (1998) and the amount of rainfall, and also by the applied dose of fertilizer, in agreement with Mora et al. (2007). Another factor that affects leaching is the stocking rates used (Ledgard et al., 1999), but not in our case, due to the stocking rate was used was the same in both grazing systems. Alfaro et al. (2005b, 2006,2007 ) indicate that the amount of OM, soil type and fertilizer application rate influence the volume of $\mathrm{N}$ leached; also $\mathrm{N}$ mineralization rate from urea could affect the amount of $\mathrm{N}$ leaching losses (Cartes et al., 2009).

The losses of nitrous oxide from urine, dung and fertilizer sources were low because the low percentage assigned to the $\mathrm{N}$ recycled as feces and urine in the methodology used (Table 4). In experiments carried out by Phillips et al. (2007), where the same estimation factors of $\mathrm{N}_{2} \mathrm{O}$ were used, similar emission values were reported for the fertilizers (2.81 kg N $\mathrm{kg} \mathrm{ha}^{-1} \mathrm{yr}^{-1}$ with a rate of 225 $\mathrm{kg} \mathrm{N} \mathrm{ha-1} \mathrm{yr}^{-1}$ applied) in temperate pastures, but emission values from urine and feces were higher (1.9-2.4 and 0.5-0.6 $\mathrm{kg} \mathrm{N}_{2} \mathrm{O} \mathrm{ha}^{-1} \mathrm{yr}^{-1}$ for urine and feces, respectively. This could be because the previous study used a stocking rate 2.4 times greater than that in the present study (300 dairy cows over $24 \mathrm{~h}$ at intervals of 14-21 days; Phillips et al. 2007).

\section{Plant uptake}

The pasture DM yield varied between 7 and $10 \mathrm{t} \mathrm{DM} \mathrm{ha}^{-1}$. The results indicate that the pasture yield varied with the grazing systems (Table 3 ). Greater production was obtained in the HG treatment $(P \leq 0.05$; Table 3). This means that a more intensive grazing results in a higher DM production, in agreement with McKenzie et al. (2006a). This treatment had the bigger yield results and the biggest $\mathrm{N}$ plant uptake $\mathrm{N}$, but also had the higher $\mathrm{N}$ losses, having therefore a bigger potential for environmental pollution.

The herbage quality of the pasture was affected by the grazing systems applied; being in the two cases higher for HG and lower in the LG treatment (Table 3).

In grazed pasture, $\mathrm{N}$ concentration increased significantly with respect to the no grazed pasture $(\mathrm{C})$, reaching in $\mathrm{HG}$ $1885.6 \mathrm{~kg}$ of crude protein per hectare per year. Although with did not observe differences in the protein concentration among $\mathrm{HG}$ and $\mathrm{LG}$, the protein produced is clearly greater in $\mathrm{HG}$ due to its higher DM yield. In this sense, McKenzie et al. (2006a, 2006b) demonstrated that an intense and frequent grazing modifies the structure and botanic composition of the pasture, increasing its quality. Similar 
results were shown by $\mathrm{Ru}$ and Fortune $(1996,2000)$ in a template pasture under irrigation.

\section{Nitrogen budgets}

The treatments with less $\mathrm{N}$ plant uptake had a greater soil $\mathrm{N}$ surplus, being this the main factor that affect $\mathrm{N}$ accumulation in the soil, in agreement with Alfaro et al. (2003). The $L G$ and the $C$ treatments were have less efficient in converting soil $\mathrm{N}$ into DM (Table 4), with a NRE by the plants of $62 \%$, on average, from the total inputs, compared to $\mathrm{HG}$ with $71 \%$. A percentage of NRE by the plants $\geq$ to $65 \%$ of the $\mathrm{N}$ inputs to the system is considered optimum (Baligar et al., 2001; Delgado, 2002) depending on the crop systems and $\mathrm{N}$ rate applied. The global average reported by NRE is 50\% (Baligar et al., 2001; van Es and Delgado, 2004). Considering this, grazing $\mathrm{HG}$ and $\mathrm{LG}$ were optimally efficient compared to the ranges established in literature.

Alfaro et al. (2005a) in a field study in a permanent pasture of Southern Chile reported negative balance results of $\mathrm{N}$ for the different treatments. The experiment used 3.5 calves as stocking rate (HolsteinFriesian with $212 \mathrm{~kg}$ initial). However, this $\mathrm{N}$ balance did not include the plant recycling, and the $\mathrm{N}$ fertilization applied was low $\left(67.5 \mathrm{~kg} \mathrm{~N} \mathrm{ha}^{-1}\right)$. In this case, the $\mathrm{N}$ deficit was associated to the lack of consideration of the $\mathrm{OM}$ mineralization and to a low fertilization. Therefore, this balance could be positive if it would be considered these variables and with this the results would have had the same tendency than that of our experiment.

\section{Nitrogen use efficiencies (NUEs)}

Nitrogen recovery efficiencies were greater in the grazing treatments. This was related to a greater DM production and plant uptake in this treatment (Table 3 ). This was due to the fact that an intense grazing reduces the amount of dead matter and senescence, facilitating the growth of new tillers, and therefore, a faster recovery of the pasture, which in turn, results in a greater $\mathrm{N}$ plant uptake and use. The efficiencies have relation with the total $\mathrm{N}$ inputs, however, the ANUE were not statistically different between treatments in agreement with the reported by (Baligar et al., 2001). These efficiencies are high compared to grazing systems from the United Kingdom, where $41-56 \%$ was reported during a period of seven years of evaluation (Leach et al., 2004). In this sense, Ledgard et al. (1999), in New Zealand pastures, reported a efficiency ( $\mathrm{N}$ in product/ $\mathrm{N}$ inputs) of $30 \%, 20 \%$ in England (Jarvis, 1993; Ledgard et al., 1999), 14\% in Holland and $23 \%$ in Switzerland (Ledgard et al., 1998) in pasture template. This way, the NRE of the pasture is higher because the $\mathrm{N}$ efficiency was not calculated based on the production of milk, meat or crop, which explains the differences between the efficiencies shown. As it was discussed in the section about the nitrogen surplus was bigger in the treatments with smaller NRE and smaller in the most intense grazing, this suggests that the plants used the $\mathrm{N}$ more efficiently on $\mathrm{HG}$; however this increases the possibilities of $\mathrm{N}$ losses in this grazing type and therefore a bigger negative impact.

The agronomic efficiency of the pasture depends on the applied $\mathrm{N}$ to the plants from the soil and on the environmental conditions, in agreement with Whitehead (2000). The values showed by ANUE from the fertilizer applied is similar to that reported by Whitehead (2000), fluctuating between 20-30 kg DM ha ${ }^{-1} \mathrm{yr}^{-1}$ at a dose of 250$400 \mathrm{~kg} \mathrm{~N} \mathrm{ha}^{-1} \mathrm{yr}^{-1}$.

According to these results, the $\mathrm{HG}$ treatment would the best grazing management for dry matter yield, quality and NUE. Nevertheless, this treatment 
also showed the greater $\mathrm{N}$ losses to the environment, in comparison to the $\mathrm{LG}$ treatment which was similar to the $\mathrm{C}$ treatment.

Alternatives to reduce the potential environmental impact of this grazing management would be to adjust fertilizer $\mathrm{N}$ input to reduce $\mathrm{N}$ surpluses, to avoid $\mathrm{N}$ fertilizer application during rainy periods, to match $\mathrm{N}$ pasture demand with $\mathrm{N}$ fertilizer application and to avoid overgrazing in winter.

\section{CONCLUSIONS}

The heavy grazing (HG) treatment had larger nitrogen recovery efficiency (NRE) than the LG and control treatments (71, 62 and $61 \%$ for the $\mathrm{HG}, \mathrm{LG}$ and $\mathrm{C}$ treatments, respectively).

Heavy grazing system facilitated the faster pasture recovery, which in turn, resulted in a greater dry matter production. Thus, the HG treatment produced a $27 \%$ more of dry matter production than the LG treatment (10383 and $8174 \mathrm{~kg} \mathrm{DM} \mathrm{ha} \mathrm{yr}^{-1}$ for both treatments, respectively).

A positive $\mathrm{N}$ budget in the treatments suggests $\mathrm{N}$ accumulation in the soil at the end of the grazing season because of the high $\mathrm{N}$ inputs, especially in the $\mathrm{HG}$ treatment (427 kg N ha ${ }^{-1}$ ). Consequently, the highest input of $\mathrm{N}$ in $\mathrm{HG}$ system resulted in $\mathrm{N}$ total losses greater by $40 \%$ than LG and $52 \%$ than no grazed systems. According to our results, the HG treatment would the best grazing management for dry matter yield, quality and nitrogen use efficiency. Thus, we recommend that farmers should consider these environmental constrains when implementing intensive grazing strategies.

\section{ACKNOWLEDGEMENTS}

Thanks to the grants DIUFRO 160603

(Universidad de La Frontera),

FONDECYT 1020934, FONDECYT

1070239, FONDECYT 1061262,

FONDEF D06I1081 and FIA (FIA-PI-C2003-1). Also thanks to the Dominican Government (Dominican Republic Institute of Agricultural and Forest Research) for funding Dr. Pedro Núñez.

\section{REFERENCES}

Alfaro, M.A. and Salazar, F. 2005. Ganaderia y contaminación difusa, implicancias para el sur de Chile. Chilean J. Agric. Res., 65, 330-340.

Alfaro, M.A., Jarvis, S.C. and Gregory, P.J. 2003. Potassium budgets in grassland systems as affected by nitrogen and drainage. Soil Use Manage., 19, 89-95.

Alfaro, M., Salazar, F., Teuber, K., Iraira, S., Villarroel, T. and Ramírez, P. 2005a. Balances de nitrógeno y fósforo en sistemas de producción de carne de la Décima Región. XXX Reunión Anual de la Sociedad Chilena de Producción Animal, 30, 181-182.

Alfaro, M., Salazar, F., Iraira, S., Teuber, N. and Ramírez, L. 2005b. Nitrogen runoff and leaching losses in beef production systems under two different stocking rates in southern Chile. Gayana Bot., 62, 130-138.

Alfaro, M.V., Salazar, F.S., Endress, D.B., Dumont J.C.L. and Valdebenito, A.B. 2006. Nitrogen leaching losses on a volcanic ash soils affected by the source of fertiliser. R.C. Suelo Nutr. Veg., 6, 54-63.

Alfaro, M.V., Salazar, F.S., Iraira, S., Teuber, N., Villaroel, D. and Ramírez, L. 2007. Nutrient losses in beef production systems of southern Chile. In: Pinoche, T.D. (Ed.), Nutrición y Alimentación de Bovinos. Efecto de la Intensificación de Sistemas Ganaderos Pastoriles. Aspectos Técnicos, Ambientales y Sanitarios. SOCHIPA, Chile, Serie. Simposio. Complemento, 12-13, 83-92. 
Alfaro, M.V., Salazar, F.S., Oenema, O., Iraira, S., Teuber, N., Ramírez, L. and Villaroel, D. 2009. Nutrients balances in beef cattle production systems and their implications for the environment. R.C. Suelo Nutr. Veg., 9, 4054.

Addiscott, T.M. 2006. Soil and Environmental issues. In: Warkenting, B.P. (Ed), Footprints in the soil. People and ideas in soil history. Elsevier, Netherlands, UK, pp. 455-501.

Baligar, V.C., Fageria, N.K. and He, Z.L. 2001. Nutrient use efficiency in plants. Commun. Soil Sci. Plan., 32, 921-950.

Bouwman, A.F., Van Drecht, G. and Van der Hoek, K.W. 2005. Global and regional surface nitrogen balances in intensive agricultural production systems for the period 1970-2030. Pedosphere, 15, 137-155.

Boeckx, P., Godoy, R., Oyarzún, C., Bot, J. and Van Cleemput, O. 2004. Resolving differences in $\mathrm{N}$ between more polluted and pristine forest using ${ }^{15} \mathrm{~N}$ isotope dilution. In Hatch, D.J., Chadwick D.R., Jarvis, S.C., Roker, J.A. (Eds), Controling nitrogen flows and losses. pp. 143-144.

Cartes, P., Jara, A.A., Demanet, R. and Mora, M.L. 2009. Urease activity and nitrogen mineralization kinetics as affected by temperature and urea input rate in southern Chilean Andisol. R.C. Suelo Nutr. Veg., 9, 69-82.

CIREN. 2003. Descripciones de suelos, materiales y símbolos, estudio agrológico $\mathrm{X}$ Región. Vol. II. Centro de Información de Recursos Naturales (CIREN), Santiago, Chile. p. 122.

Di, H.J. and Cameron, K.C. 2004. Treating grazed pasture soil with a nitrification inhibitor, eco- $\mathrm{n}^{\mathrm{TM}}$, to decrease nitrate leaching in a deep sandy soil under spray irrigation- a lysimeter study. New Zeal. J. Agric. Res., 47, 351-361.

Delgado, J.A. 2002. Quantifying the loss mechanisms of nitrogen. J. Soil Water Conserv., 57, 389-398.

Godoy, R., Oyarzún, C. and Gerding V. 2001. Precipitatation chemistry in deciduous and evergreen Nothofagus forests of southern Chile under a low-deposition climate. Basic Appl. Ecol., 2, 65-72.

Godoy, R., Paulino, L., Oyarzún, C. and Boeckx, P. 2003. Atmospheric $\mathrm{N}$ deposition in central and southern Chile. An overview. Gayana Bot., 60, 47-53.
Haynes, R.J. and Williams, P.H. 1993. Nutrient cycling and soil fertility in the grazed pasture ecosystem. Adv. Agron., 49, 119-199.

IPCC. 1997. Revised 1996. IPCC Guidelines for National Greenhouse Gas Inventories. Module 4 Agriculture. Available at: http://www.ipccnggip.iges.or.jp/public/g1/invs1.htm.

INE. 2007. Informe estadísticas agropecuarias para el periodo 2001-2006 y primer semestre 2007. Available at: $<\mathrm{http}: / / \mathrm{www}$.ine.cl/canales/

chile_estadistico/estadisticas_agropecuarias/pdf/ pecuarioprimersemestre2007_2.pdf>.

Jarvis, S.C. 1993. Nitrogen cycling and losses from dairy farms. Soil Use Manage., 9, 99-105.

Jarvis, S.C. 1997. Emission processes and their interactions in grassland soils. In: Jarvis, S.C.,Pain, B.F. (Eds), Gaseous nitrogen emissions from grasslands, $\mathrm{CAB}$ International, pp. 1-18.

Jarvis, S.C. and Ledgard, S. 2002. Ammonia emissions from intensive dairying: a comparison of contrasting systems in the United Kingdom and New Zealand. Agr. Ecosyst. Environ., 92, 83-92.

Leach, K.A., Goulding, K.W.T., Hatch, D.J., Conway, J.S. and Allingham, K.D. 2004. Nitrogen balances over seven years on a misex farm in the cotswords. In: Hatch, D.J., Chadwick D.R., Jarvis, S.C., Roker, J.A. (Eds), Controlling nitrogen flows and losses. Institute of Grassland and Environmental Research, UK. pp. 39-46.

Ledgard, S.F., Crush, J.R. and Penno, J.W. 1998. Environmental impacts of different nitrogen inputs on dairy farms and implications for the Resource Management Act of New Zealand. Environ. Pollut., 102, 515-519.

Ledgard, S.F., Penno, J.W. and Sprosen, M.S. 1999. Nitrogen inputs and losses from clover/grass pastures grazed by dairy cows, as affected by nitrogen fertilizer application. J. Agr. Sci., 132, 215-225.

Ledgard, S.F., Sprosen, M.S., Penno, J.W. and Rajendram, G.S. 2001. Nitrogen fixation by white clover in pastures grazed by dairy cows Temporal variation and effects of nitrogen fertilization. Plant Soil, 229, 177-187.

Lesschen, J.P, Stoorvogel, J.J., Smaling, E.M.A., Heuvelink, G.B.M. and Veldkamp, A. 2007. A spatially explicit methodology to quantify soil nutrient balances and their uncertainties at the national level. Nutr. Cycl. Agroecosys., 78, 111-131. 
McKenzie, F.R., Jacobs, J.L. and Kearney, G. 2006a. Effects of spring grazing on dryland perennial ryegrass/white clover dairy pastures. 1 . Pasture accumulation rates, dry matter consumed yield, and nutritive characteristics. Aust. J. Agr. Res., 57, 543-554.

McKenzie, F.R., Jacobs, J.L. and Kearney, G. 2006b. Effects of spring grazing on dryland perennial ryegrass/white clover dairy pastures. 2 . Botanical composition, tiller, and plant densities. Aust. J. Agr. Res., 57, 555-563.

Mora, M.L., Cartes, P., Núñez, P., Salazar, M. and Demanet, R. 2007. Movement of $\mathrm{NO}_{3}{ }^{-} \mathrm{N}$ and $\mathrm{NH}_{4}{ }^{+}-\mathrm{N}$ in an Andisol and its influence on ryegrass production in a short term study. R.C. Suelo Nutr. Veg., 7, 46-63.

Meteorology Direction of Chile. 2005-2006. Maquehue Station. Temuco, City. Daily registrations. Temuco, Chile.

National Greenhouse Gas Inventory Commitee (NGGIC). 2005. Australian Methodology for Estimation of Greenhouse Gas Emissions and Sinks 2005: Agriculture. Australian Greenhouse Office, Departament of Environment and Heritage, Camberra, Australia.

Núñez, R.P.A. 2008. Efecto de la frecuencia e intensidad de pastoreo en las pérdidas de nitrógeno en una pradera permanente del Sur de Chile. Tesis Doctorado en Ciencias de Recursos Naturales. Universidad de La Frontera. Temuco, Chile. 186 p.

Núñez, P., Demanet, R., Misselbrook, T.H., Alfaro, M. and Mora, M.L. 2010. Nitrogen losses under different cattle grazing frequencies and intensities in a volcanic soil of southern Chile. Chilean J. Agric. Res., 70 (2):237-250.

Oyarzún, C.E., Godoy, R. and Leiva, S. 2002 Atmospheric deposition of nitrogen in a transect from the central valley to Cordillera de Los Andes, south-central Chile. Rev. Chil. Hist. Nat., $75,233-243$

Phillips, F.A., Leuning, R., Baigenta, R., Kelly, K.B. and Denmead, O.T. 2007. Nitrous oxide flux measurements from an intensively managed irrigated pasture using micrometeorological techniques. Agr. Forest Meteorol., 143, 92-105.

Reyes, J., Vidal, I., Gónzales, M. and Fonte, D. 2000. Three grazing intensities on nitrogen soil recycling. Cuban J. Agr. Sci., 34, 201-206.

Ru, Y.J. and Fortune, J.A. 1996. Hard grazing during spring growth improve nutritive value of subterranean clover. Proceedings of Australian Society of Animal Production, 21, 423.
Ru, Y.J. and Fortune, J.A. 2000. Effect of grazing intensity and cultivar on morphology, phenology, and nutritive value of subterranean clover II. Nutritive value during the growing season. Aust. J. Agric. Res., 51, 1047-1055.

Ryden, J.C. 1986. Gaseous losses of nitrogen from grassland. In: van der Meer, H.G, Ryden, J.C.,Ennik, G.C. (Eds), Nitrogen fluxes in intensive grassland systems. Martinus Nijhoff Publishers, Dordrecht, pp. 59-73.

Ryden, J.C., Ball, P.R. and Garwood, E.A. 1984. Nitrate leaching from grasslands. Nature, $311,50-53$

Sadzawka, A., Grez, Z.R., Mora, M.L., Saavedra, R.N., Carrasco, M.A. and Rojas, W.C. 2000. Métodos de análisis recomendados para los suelos chilenos. Comisión de Normalización y Acreditación (CNA), Sociedad Chilena de la Ciencia del Suelo, Chile.

Sadzawka, A., Carrasco, M.A., Demanet, R. Flores, H., Grez, Z.R., Mora, M.L. and Neaman, A. 2007. Métodos de análisis de tejidos vegetales. Comisión de Normalización y Acreditación (CNA), Sociedad Chilena de la Ciencia del Suelo, Chile. $2^{\text {da }}$. Edición. Series Actas INIA 40, $140 \mathrm{p}$.

Saggar, S., Andrew, R.M., Tate, K.R., Hedley, C.B., Rodda, N.J. and Townsend, J.A. 2004. Modelling nitrous oxide emissions from dairy grazed pastures. Nutr. Cycl. Agroecosys., 68, 243-255.

SAS Institute. 2002. JMP 5.0.1.2. The statistical discovery software 2002. SAS Institute Inc. Campus Drive, Cary, North Carolina, USA.

Searle, P.L. 1984. The Berthelot or indophenol reaction and its use in the analytical chemistry of nitrogen. a review. The Analyst, 109, 549-568.

Sommer, S.G. and Jensen, C. 1994. Ammonia volatilization from urea and ammoniacal fertilizers surface-applied to winter-wheat and grassland. Fert. Res., 37, 85-92.

Urzúa, H. 2005. Beneficios de la fijación simbiótica de nitrógeno en Chile. Cien. Inv. Agr., $32,133-150$

Van Es, H.M. and Delgado, J.A. 2004. Nitrate Leaching Index. In: Dekker, M. (Ed), Encyclopedia of Soil Science., New York, pp. 1-3.

Whitehead, D.C. 2000. Nutrient elements in grassland: Soil-plant-animal relationschips. 1/Ed. $\mathrm{Cab}$ International publishing. AMA Graphics Ltd, Preston, Tucson, UK. 